\begin{tabular}{|l|l|l|l|l|l|}
\hline Senckenbergiana lethaea & 82 & $(1)$ & $153-166$ & 12 Fig., 3 Tab. & Frankfurt am Main, 30.6.2002 \\
\hline
\end{tabular}

Concepts of Functional, Engineering and Constructional Morphology ${ }^{*}$

\title{
Food-specialization and structural parameters of Dental Patterns of Arvicolinae (Rodentia, Mammalia)
}

\author{
With 12 Figures and 3 Tables
}

NICOLE HERRMANN

\begin{abstract}
In this study it is demonstrated that food-specialization of different species of voles and lemmings is reflected in their dental patterns. The subfamily of Arvicolinae was chosen because the basic structure of the occlusal patterns of their molars is very stereotypical and thus their modifications can be attributed to differences in function. The properties of their M2 occlusal patterns are expressed by structural parameters such as pattern density, relative enamel surface and orientation of the enamel edges. Marked differences were found between grass- and moss-feeding species on the one hand as well as root-feeding species on the other. Differences of construction of walls of plant cells of the firmness tissues determine the kind of fooddisintegration. The grass- and moss-feeders have evolved a dentition with high pattern density, low relative enamel surface and a high degree of orientation of the enamel bands. The root-feeders have a dentition with low pattern density, high relative enamel surface and a low degree of orientation. Species, which often feed on seeds or have a wide range of diet, are located between them.
\end{abstract}

Key words: Rodentia, Arvicolinae, dental pattern, structural parameters, food-specialization

\section{Introduction}

Recent voles and lemmings (Arvicolinae) are small rodents, which evolved from Cricetidae in Upper Miocene (NIETHAMMER, 1988). The dental patterns of their molars are very characteristic and show different stages of adaptation to a diet of grasses or mosses. From a methodological point of view, arvicolids are one of the best groups for studying the change of dental patterns, for the following reasons:

The occlusal patterns of Recent voles and lemmings are variations of the same basic morphological type and their teeth are progressively high crowned or even rootless hypsodont. The propalinal mastication with a protinal direction of powerstroke produces a flat occlusal pattern which can be very well analysed utilizing two-dimensional digital image processing.
All species of arvicolids are mainly herbivorous and live in Holarctic region. In spite of this, differences in dental pattern are clearly shown. The analysis of the measured parameters such as pattern density, relative enamel surface and orientation of the enamel bands allow to distinguish 1) species, which mainly feed on leaves or sprouts of plants (mainly grass), 2) species, which mostly feed on roots, and 3) species with a high amount of seeds in their diet. The structural parameters used show very clearly gradually changing dental patterns with regard to the various degrees of food-specialization.

This study continues the DFG-project Schm 452/13 and is the first part of my dissertation.

*) Special issue of Senckenbergiana lethaea, edited by Michael Gudo, Mathias Gutmann \& Joachim Scholz 


\section{Material and Method}

\section{Material}

The material studied belongs to the collections of Forschungsinstitut Senckenberg (Frankfurt), Staatliches Museum für Naturkunde (Schloss Rosenstein, Stuttgart) and University of Mainz. It consists of 627 molars of Arvicolinae, 331 teeth of the upper and 296 of the lower jaw. Table 1 shows details.

\section{Method}

RENSBERGER wrote 1973 that there are 'relationships between dental morphology and the processes of food disintegration, food movement and dental wear'. Change of the three following features shows the specialization of cheek teeth to a diet consisting of grass or moss in particular: length, thickness and orientation of the enamel bands (KOENIGSWALD, 1980).

In this study, M2 was selected because the middle position prevents an unlimited increase in the number of dentin triangles of the occlusal pattern. This explains why the occlusal patterns of M2 are very stereotypic within the arvicolids. The following measurements were necessary: Occlusal surface, perimeter of the dental pattern and surface of the enamel bands. Drawings were produced manually and digitalized later. The measurements were made with the measuring program OPTIMAS. For the determination of orientation of enamel bands, the pixel-images were fixed vectorially with ARC on UNIX. In this study, the description of molars from KOENIGSWALD $(1980$, p.12) is applied.

\section{Structural parameters}

\section{Pattern density (parameter D)}

The prolongation of the enamel bands raises the effectivity of the tooth (KoENIGSWALD, 1980). In the arvicolids, this is achieved by an increasingly alternating position of dentin triangles, which makes it possible that the limbs of triangles could be longer. Pattern density is described using the parameter D (SCHMidT-KiTTLER, 1984, 1986 and this tome). This parameter is calculated as follows:

$$
\mathrm{D}=\mathrm{U}^{2} /\left(\mathrm{F}_{\mathrm{ges}} * 4 \Pi\right)
$$

The parameter D is positively correlated to the body mass of the species and increases proportionally with an increasing number of shape-elements of the occlusal patterns (SCHMIDTKITTLER, this volume). A circle has the value 1 . The more the patterns are folded the higher is parameter D. Since voles and lemmings have nearly the same body mass and the number of shape-elements (dentin triangles) in the M2 is constant, a comparison of the $D$-values is possible.

SCHMIDT-KITTLER in this volume describes the limits of application of this parameter.

\section{Relative enamel surface (parameter Sf)}

Thickness of the enamel bands is an even more important feature, which makes it possible to distinguish the respective spe- cies with regard to their diet. This feature determines the kind of mechanical disintegration of food. Relative enamel surface expressed as the ratio of the surface of the enamel band and the occlusal surface has first been measured by SCHMIDT-KITTLER, 1984. In the present article it is expressed in a slightly other way. The parameter Sf describes the relative enamel surface and represents the percentage of the surface of the enamel band $\mathrm{F}_{\mathrm{Sf}}$ with regard to the entire wear surface $\mathrm{F}_{\text {ges }}$ :

$$
\operatorname{Sf}(\%)=\left(F_{\text {Sf }^{*}} 100\right) / F_{\text {ges }} \text {. }
$$

In many genera of arvicolids (e.g. Microtus, Arvicola, Dicrostonyx) the thickness of trailing edges (lee) is reduced, so that they have no relevance for cutting process. Nevertheless, the trailing edges are important for the stability of the occlusal surface of the tooth. If the trailing edges are completely reduced, the dentine behind the leading edges would more deeply excavated and the wear surface would not be flat. That is why the complete enamel surface is considered. Application of the parameter Sf is limited to high crowned, respectively rootless hypsodontous species. Concerning the low crowned (bunodontous) teeth, the occlusal surface is rising with an increase in wear. On the other hand, the enamel surface is barely changing. This leads to a seeming decrease of the parameter Sf with progressive abrasion.

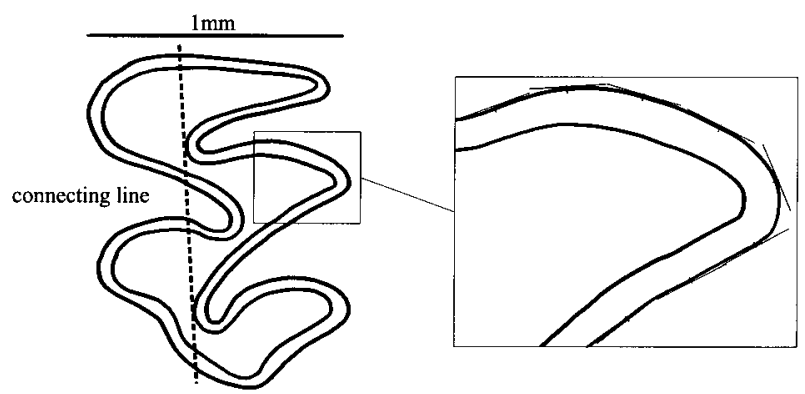

Text-fig. 1. Reference line (similar to the direction of chewing motion) and tangents drawn on the outline of the enamel band.

\section{Uniformity of orientation of the enamel edges (parameter $G$ )}

The direction of enamel edges with regard to the direction of powerstroke (occlusal motion) influences the effectivity of the food-disintegrating process. The functional importance of this was already recognized by MAGLIO, (1972), KOENIGSWALD, (1980), RENSBERGER ET AL (1984). SCHMIDT-KITTLER, this volume, defined a parameter describing the degree of uniformity of orientation of the enamel bands in order to compare this feature within the species. To obtain this parameter, tangents were drawn on the outline of enamel bands (not on the total occlusal outline), in regular distances from each other and the angle of a chosen direction, which fix the $0^{\circ}$ orientation, was calculated (text-fig. 1). In order to get the absolute angles of tangents to the chewing direction a reference line $\left(0-180^{\circ}\right.$-line $)$ is necessary. In arvicolids the chewing direction nearly corre- 
sponds to a connecting line between the first and second labialsynclines of the $\mathrm{M}^{2}$ and the first and second lingual-synclines of $\mathrm{M}_{2}$ (text-fig. 1). The percentage of the tangents was determined then within the class-boundaries of $10^{\circ}$ in a range from 1 to $180^{\circ}$. This means, that an angle of e.g. $200^{\circ}$ corresponds to an angle of $20^{\circ}$ and so on. In the rose diagrams all tangents measured were put through the centre of the circle, so that a full circle arises. This circle can now be divided into quadrants. Parameter $G$ is the ratio of the first quadrant with the biggest number of tangents and the neighbouring quadrant which contains the smallest number of tangents (text-fig. 2).

Rose diagrams showing directions of tangents represent the direction of enamel edges to the direction of powerstroke. The dominant orientation of the enamel edges can be read off directly, however the different directions of powerstroke of the jaws and the reflection of the dental patterns at the symphysis must be noted. The rose diagrams of this study were modified in a manner that they represent the orientation of the enamel bands of the right molars. The calculation of the parameter $G$ does not really need a defined $0-180^{\circ}$ line. The position of this line can be chosen at pleasure because parameter $G$ describes a relative ratio, but the possibility to get the absolute angles of tangents in regard of the direction of chewing motion is not

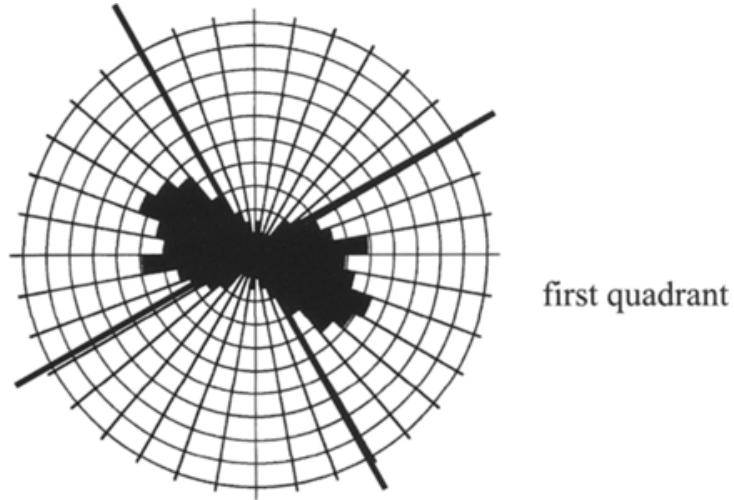

second quadrant

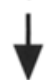

direction of chewing motion

Text-fig. 2. Arrangement of two neighbouring quadrants to calculate parameter $\mathrm{G}$ (Microtus arvalis; distance circle-to-circle equals $2 \%$ ).

\section{Results and discussion}

\section{Results}

The occlusal patterns of M2 of the upper and lower jaws differ in the number of shape elements (except Dicrostonyx groenlandicus, $D$. torquatus and Microtus agrestis). This is why only the values of the upper cheek teeth were taken for the comparison of the species. A comparison of the lower cheek teeth shows the same (Tab. 4).
In species with rootless molars the changes of the occlusal patterns with an increase of wear are not relevant. Variability of dental patterns of species with rootless molars is trifling (text-fig. 3). The dental patterns of the species with rooted molars changed slightly with increasing abrasion (the enamel band became somewhat shorter and thicker), which means the values vary more within the species (text-fig. 4). Nevertheless, the clouds of values are close enough to apply mean values.
Text-fig. 3. Variability of dental patterns of the upper $\mathrm{M}^{2}$ of species with rootless molars.

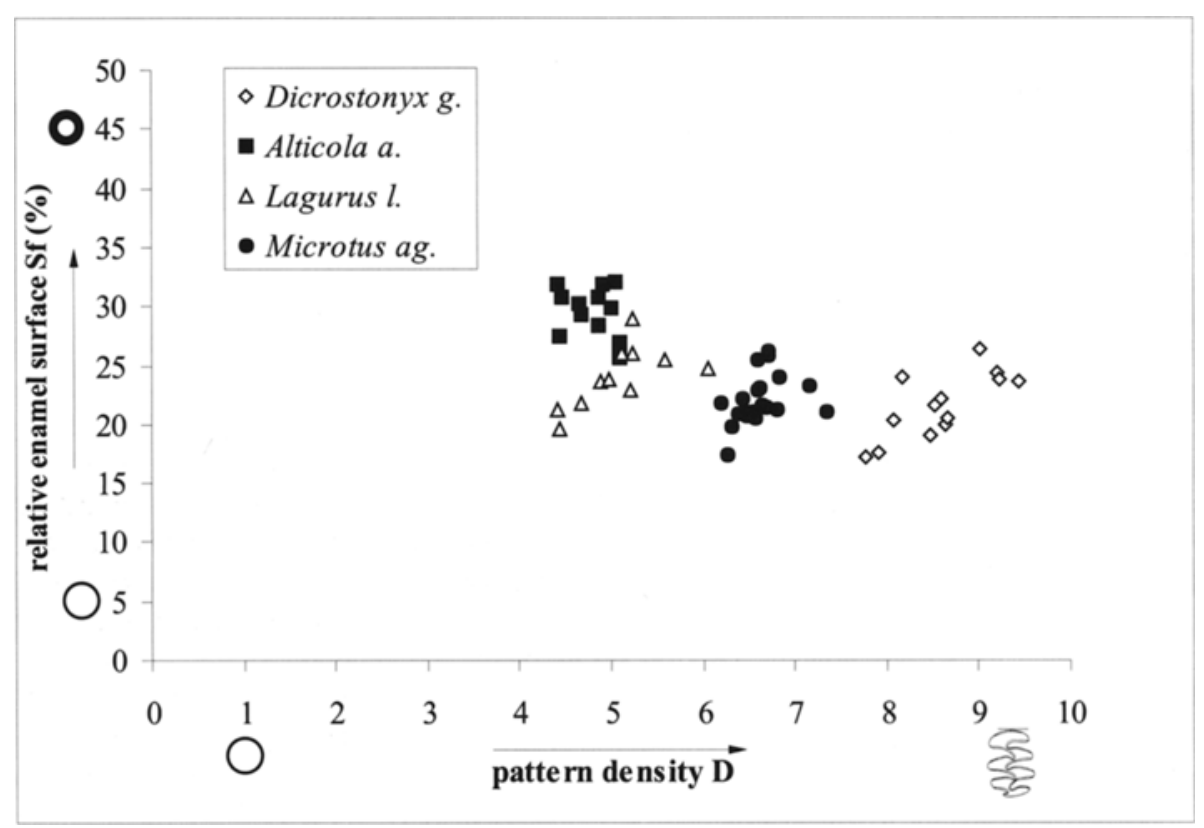




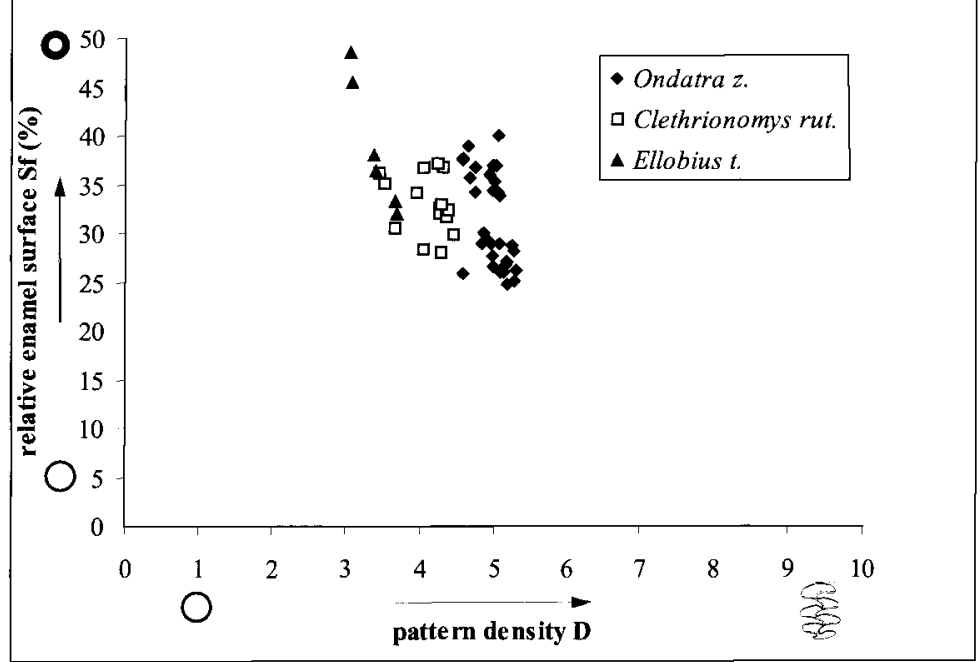

Text-fig. 4. Variability of dental patterns of the upper $\mathrm{M}^{2}$ of species with rooted molars.

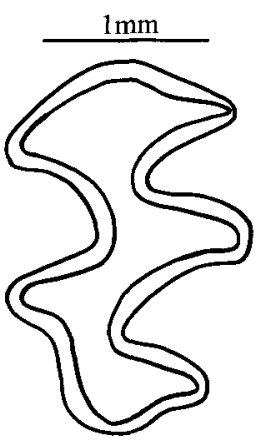

Ellobius talpinus

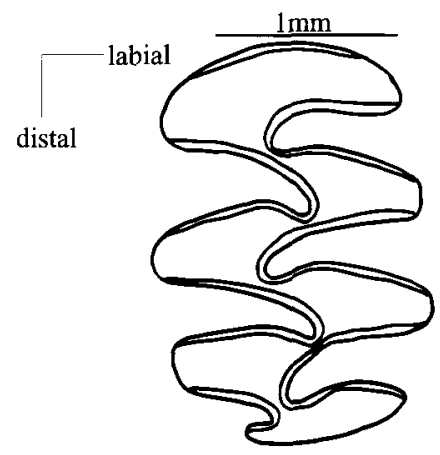

Dicrostonyx groenlandicus
Text-fig. 5. Typical occlusal pattern of upper $\mathrm{M}^{2}$ of Arvicolinae (Ellobius) and occlusal pattern of Dicrostonyx with two additional dentin triangles.

\section{Parameter D}

The pattern density D of the analysed species is different (Tab.2). Dicrostonyx has the highest D-value with 8.63 and Prometheomys has the lowest one with 3.22 . The D-values show a clear separation between Ellobius fuscocapillus, E. nitedula, E. talpinus and Prometheomys on the one hand and Dicrostonyx groenlandicus, D. torquatus, Lemmus lemmus, Myopus schisticolor, Microtus arvalis, M. agrestis and $M$. oeconomus on the other (text-fig. 6).

The high D-value of Dicrostonyx is a result of an increase in the number of dentin triangles of M2 (text-fig. 5). One additional labial- and lingual-anticline is present in the upper $\mathrm{M}^{2}$, and an additional lingual-anticline in the lower $\mathrm{M}_{2}$. Likewise, the $\mathrm{M}^{2}$ of Microtus agrestis is different from the basic patterns of arvicolids with an additional lingual-anticline (text-fig. 12). This is why the D-value of $M$. agrestis is clearly higher than those of $M$. arvalis and $M$. oeconomus.

\section{Parameter Sf}

Thickness and surfaces of enamel bands of the arvicolids vary to a high degree. Also, the Sf-values show a clear separation between Ellobius fuscocapillus, E. nitedula, E. talpinus, Prometheomys and Dicrostonyx groenlandicus, D. torquatus, Lemmus lemmus, Myopus schisticolor, Microtus arvalis, M. agrestis and $M$. oeconomus (text-fig. 6). The values of the last mentioned species, e.g. Dicrostonyx, are lower than $25 \%$, the values of the other, e.g. Ellobius are above $36 \%$ (table 2). With $17.9 \%$ Microtus oeconomus has the lowest value. Sf-values lower than this are not to be expected (in dental patterns of arvicolids) because the stability of the enamel bands would be too small. The difference of abrasion-rate on the enamel and dentin surfaces would become equalized so that the relief of occlusal surface would disappear completely, and a cutting function would no longer possible (SCHMIDT-KITTLER, this volume). There is a negative correlation between parameters D and Sf (text-fig. 6) what means that species with more folded dental patterns, e.g. Dicrostonyx torquatus, have less enamel surfaces than species with simple dental patterns (e.g. Prometheomys).

\section{Parameter $G$}

The uniformity of orientation of enamel bands increases the efficiency of the mastication process in a protinal chewing direction in which all enamel bands exert the same pressure on the food. In highly specialized dentitions of rodents, e.g. Chinchilidae, the cutting edges were more uniformly orientated (MÖDDEN, 1993). Arvicolids do not show these high adaptations because their occlusal pattern consists of dentin triangles, thus, a uniform orientation of all enamel bands is not possible. Parameter $\mathrm{G}$ is positively correlated to parameter $\mathrm{D}$ and negatively to parameter Sf (text-fig. 7). As a whole the variability of parameter $\mathrm{G}$ is not so high, because of the similar basic morphological patterns of M2 of arvicolids. The values of the genera Dicrostonyx, Lemmus and Myopus are higher than those of analysed species of Microtus because the enamel band is absent at all vertexes of the anticlines of their dentin triangles (text-fig. 12). Nevertheless, the G-values of Ondatra and Prometheomys are also relatively high. 
Text-fig. 6. Relationship between pattern density $\mathrm{D}$ and relative enamel surface Sf. (1) Alticola argentatus, (2) Alticola roylei montosa, (3) Alticola semicanus, (4) Arvicola sapidus, (5) Arvicola terrestris, (6) Clethrionomys glareolus, (7) Clethrionomys rufocanus, (8) Clethrionomys rutilus, (9) Dicrostonyx groenlandicus, (10) Dicrostonyx torquatus, (11) Ellobius fuscocapillus, (12) Ellobius nitedula angelus, (13) Ellobius talpinus, (14) Lagurus curtatus, (15) Lagurus lagurus, (16) Lemmus lemmus, (17) Microtus agrestis, (18) Microtus arvalis, (19) Microtus oeconomus, (20) Myopus schisticolor, (21) Ondatra zibethicus, (22) Pitymys lusitanicus, (23) Pitymys subterraneus, (24) Prometheomys schaposchnikovi

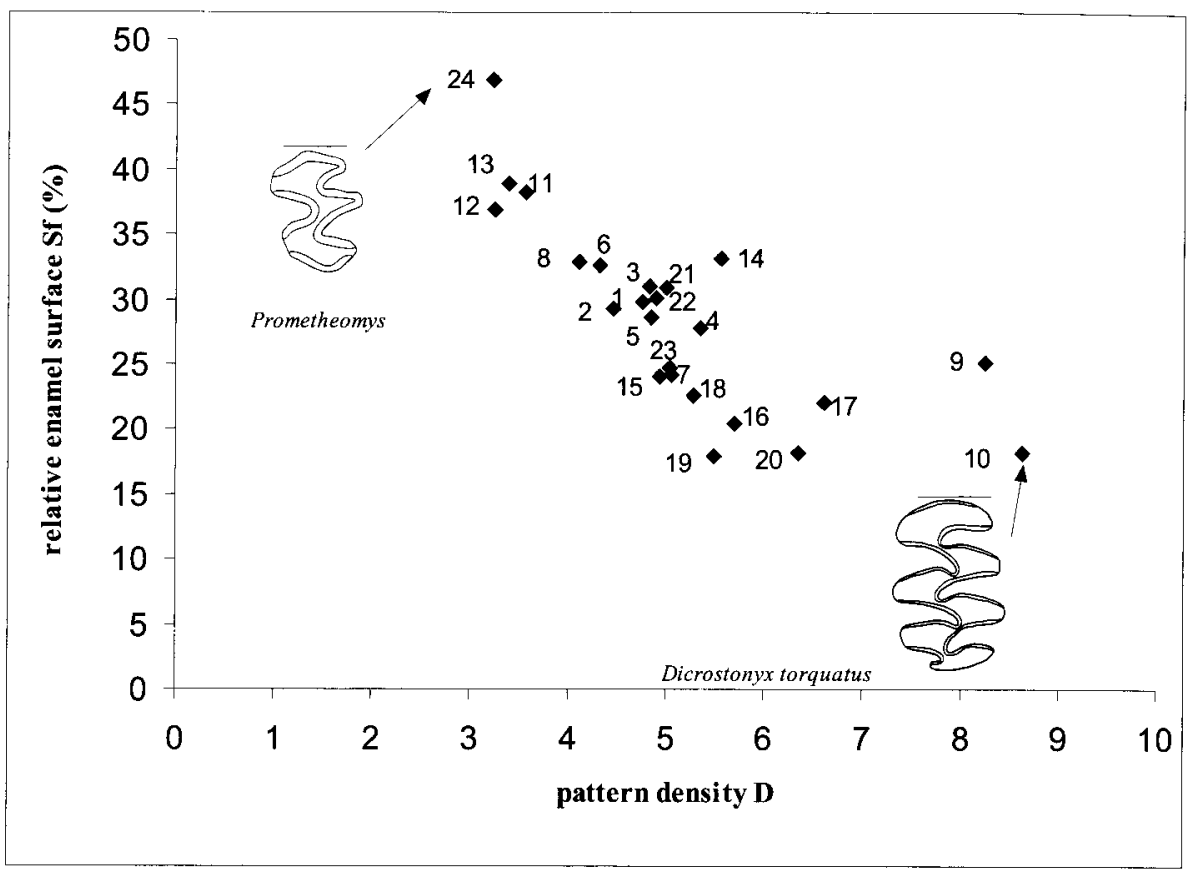

\section{Direction of enamel bands (direction-roses)}

Enamel edges must have a particular angle to the chewing direction and powerstroke, because otherwise, they would not be of functional relevance. Enamel bands, which are standing exactly rectangular to the direction of chewing motion, would offer the highest resistance and the whole width would be in function at the same time. Muscles would have to exert very high forces in order to overcome this resistance (KOENIGSWALD, 1980). To avoid these effects, enamel edges are orientated in a small angle to the direction of chewing motion so that the force needed is lower. At the same time, surfaces of contact between the enamel edges of upper and lower molars decrease and there is no cutting function over the whole length of enamel bands. Diagonal direction of enamel bands is enables a lateral food movement, which is largest at an angle of $45^{\circ}$ or $135^{\circ}$ to direction of chewing motion (RENSBERGER, 1973). Tangents on the outline of enamel bands were measured in a range from $1-180^{\circ}$ and graphical presentations through rose diagrams were made (text-fig. 8). In spite of the generally not very high orientation index $G$ (due to the special patterns of arvicolids), a preferred angle to the chewing direction is shown in many species. Most tangents have angles between $70-90^{\circ}$ (Dicrostonyx groenlandicus, D. torquatus, Lemmus lemmus, Myopus schisticolor) or 100-120 (Microtus agrestis, M. arvalis, M. oeconomus) to the direction of chewing motion. Horizontal pressure on enamel edges is relatively high in angles so little deviated from $90^{\circ}$. This is why the installation of lamellar enamel is necessary in order to withstand stress from all sides and breakage. Angles of $70-90^{\circ}$ prevent an excessive lateral motion of food so that, e.g. leaves of grasses, will be compressed and cut between upper and lower molars. Most tangents on the outline of the enamel band of Ellobius have an angle between $60-80^{\circ}$ and of Clethrionomys between $120-130^{\circ}$ to the chewing direction (text-fig. 8).

\section{Functional morphology of occlusal patterns and diet}

A clear separation of the values of D and Sf of the species Ellobius fuscocapillus, E. nitedula, E. talpinus and Prometheomys on the one hand and Dicrostonyx groenlandicus, D. torquatus, Lemmus lemmus, Myopus schisticolor, Microtus arvalis, $M$. agrestis and $M$. oeconomus on the other is shown in text-fig. 6 . The differences in the dental patterns are related to differences in dietary behaviours (RENSBERGER, 1995).

The arvicolids are characterized by two different specializations of food. There are subterraneous species, which mostly feed on roots, e.g. Ellobius fuscocapillus, E. nitedula, E. talpinus and Prometheomys (SPITZENBERGER, 1965, SIEGEL-CAUSEY AND HOFFMANN, 1992), and species which feed on leaves or sprouts of plants, mainly of grass or moss, e.g. Microtus agrestis, $M$. arvalis, $M$. oeconomus, Dicrostonyx torquatus, $D$. groenlandicus, Lemmus lemmus, Myopus schisticolor, Clethrionomys rufocanus (NIETHAMMER, 1988). There are also species, which consume a high amount of seeds, e.g. Alticola roylei montosa, Clethrionomys glareolus and C. rutilus (NIETHAMMER, 1988). Most species have a varied diet and feed also on other plants (e.g. water plants), different plant parts or insects and molluscs corresponding to seasonal changes in their habits. In summer, most species feed on leaves and sprouts of grass and moss or herbals and in winter on roots, seeds and barks.

\section{Prolongation and reduction of enamel bands}

Plants are rich on cellulose and more or less tough fibres and therefore are not easy to be subdivided. In addition, the content of energy is small. This means that more food per time must be disintegrated than with a mixed diet consisting e.g. of seeds, fruits and insects. For this reason, a prolongation of enamel bands is necessary in order to have more cutting edges on the occlusal area. Species with lengthened enamel bands have a 

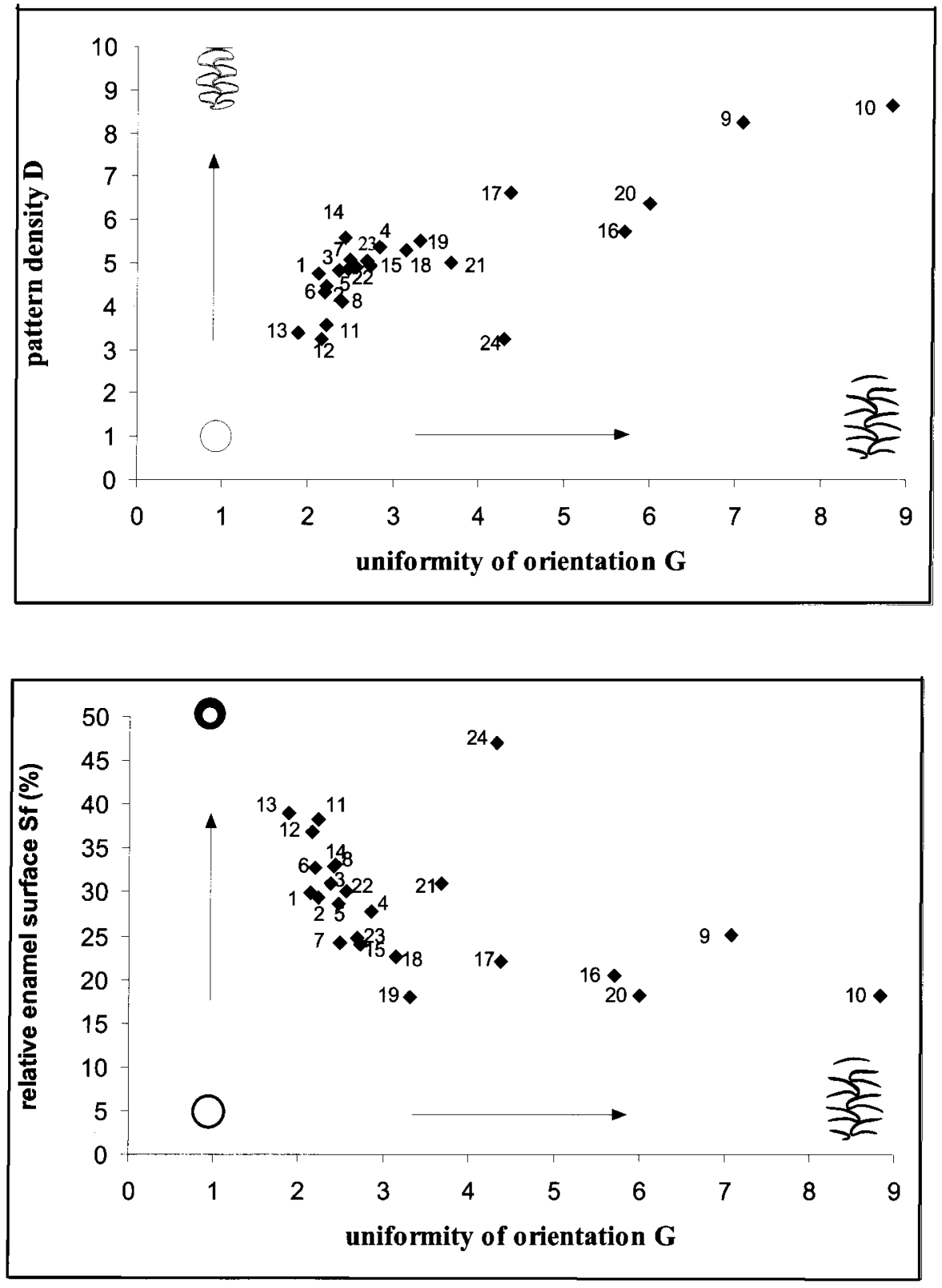

Text-fig. 7. Relationship between the parameters $\mathrm{D}, \mathrm{Sf}$ and $\mathrm{G}$.

(1) Alticola argentatus,

(2) Alticola roylei montosa,

(3) Alticola semicanus,

(4) Arvicola sapidus,

(5) Arvicola terrestris,

(6) Clethrionomys glareolus,

(7) Clethrionomys rufocanus,

(8) Clethrionomys rutilus,

(9) Dicrostonyx groenlandicus,

(10) Dicrostonyx torquatus,

(11) Ellobius fuscocapillus,

(12) Ellobius nitedula angelus,

(13) Ellobius talpinus,

(14) Lagurus curtatus,

(15) Lagurus lagurus,

(16) Lemmus lemmus,

(17) Microtus agrestis,

(18) Microtus arvalis,

(19) Microtus oeconomus,

(20) Myopus schisticolor,

(21) Ondatra zibethicus,

(22) Pitymys lusitanicus,

(23) Pitymys subterraneus,

(24) Prometheomys schaposchnikovi. more folded pattern and, consequently, have a higher parameter D. The greater number of contacts between the enamel edges on the opponent occlusal surfaces leads to a subdivision of the vertical masticatory force in many punctual pressure components (SCHMIDT-KITTLER, this volume).

On the other hand, a prolongation of the enamel bands on the same area leads to a diminution of the space between the edges where the food will be compressed. More food brought between the jaws at the same time could prevent contacts between the opposing cutting edges and thus hinder the effect of cutting separation. The reduction of uneffective parts of the enamel bands is a solution to this problem. So, in progressive species the enamel band are mostly absent on the vertexes of the anticlines and the trailing edges are reduced (KOENIGSWALD, 1980). That is why the prolongation of enamel bands is connected with a reduction of enamel surfaces. Consequently, a negative correlation between parameters $\mathrm{D}$ and $\mathrm{Sf}$ is found (text-fig. 9).

The teeth must subdivide fibres to a uniformly small size because the cell walls resist digestion (JANIS AND FORTELIUS, 1988). That is why high pressure is necessary to break up the cell walls of plants. The vertical pressure increases with decrease of enamel surface. Since the overall surface (Sf) of the enamel bands on the occlusal surface controls the rate of tooth abrasion. A reduction of the thickness of the enamel bands leads to rootless teeth. When hypsodont molars become rootless there are new requirements of stability for the cutting edges. As to this, the enamel of voles and lemmings show a singular adaptation within the rodents. The functional enamel band always consists of an inner layer of lamellar enamel and an outer layer of radial enamel. The lamellar enamel is a system, which might be able to withstand stress from all sides (KoENIGSWALD, 1980, 1994). 
Text-fig. 8. Rose diagrams of directions of enamel edges of species with different diets (distance circleto-circle equals 2\%). (1) Ellobius talpinus (roots), (2) Ondatra zibethicus (mainly water plants), (3) Clethrionomys glareolus (many seeds), (4) Microtus arvalis (mainly grass), (5) Lemmus lemmus (moss), (6) Dicrostonyx torquatus (leaves and grass).

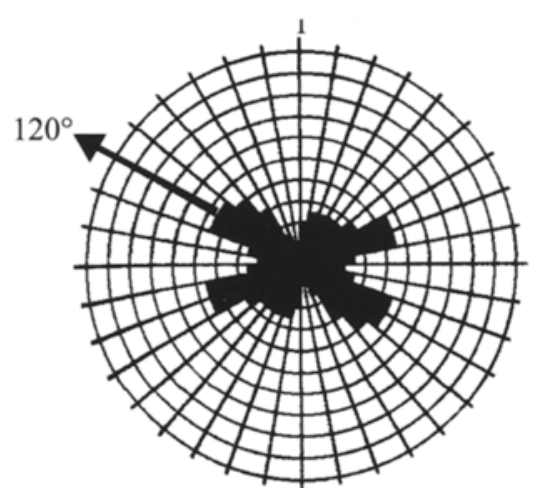

3
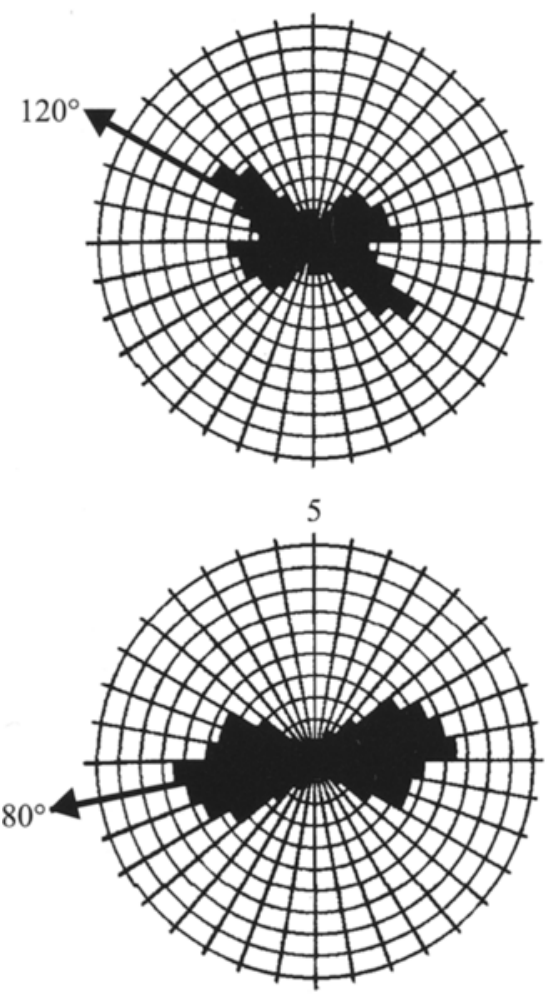

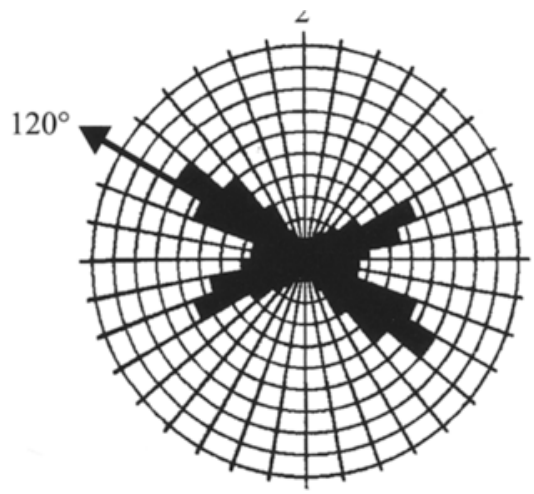

4
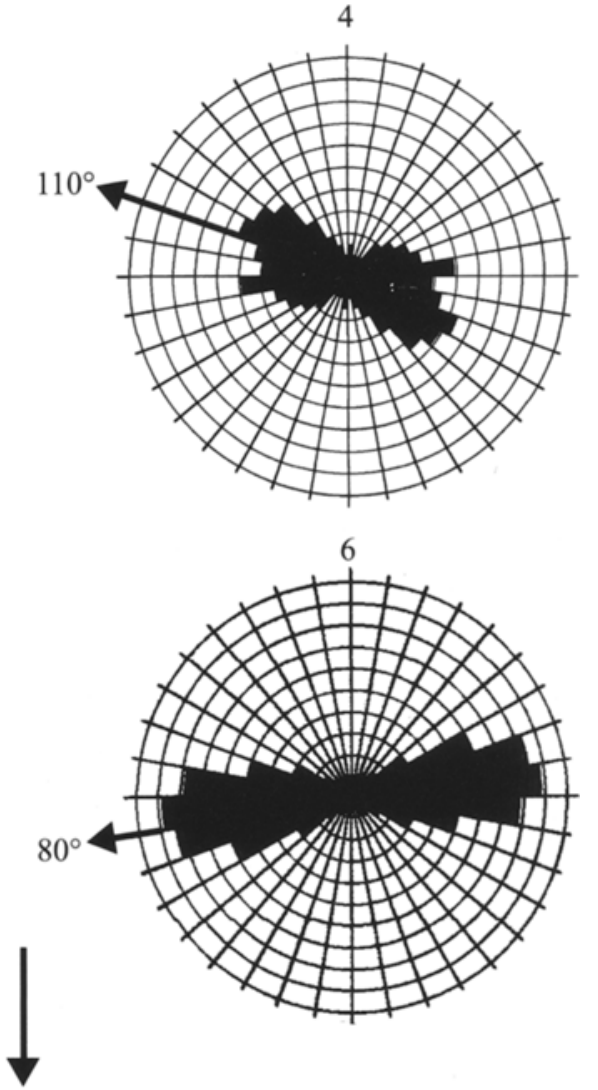

chewing direction
Species, which mostly feed on roots or seeds, have occlusal patterns with thick enamel bands. Thick and blunt enamel bands mostly consist of radial enamel, which has a high wear resistance (KOENIGSWALD, 1980). In additition, the vertical masticatory pressure will distribute among the big enamel surfaces. This is necessary to crush seeds or roots. Therefore, the abrasion of this food is very slow. That is why there is no need to develop rootless molars.

\section{Anatomy of plants and food-disintegration}

Text-fig. 9 shows the contrast between leaf (of grass) feeders with high D-values and low Sf-values on the one hand and root-feeders with low D-values and high Sf-values on the other. Species, which often feed on seeds, are located between them. The marked differences in dental patterns lead to the assumption, that the consistencies of the food plants and parts of them may play an important role in it. Therefore, it is necessary to inspect the anatomy of plants with regard to different disintegration processes.

Breaking up leaves, sprouts, roots and seeds to small pieces seems to have different requirements on the occlusal pattern. Toughness of plant fibres is dependent on the function of the respective plant part. Strengthening tissues (MOSBRUGGER, 1990) consist of collenchym and sclerenchym cells. Collenchym cells have partly thickened walls, but they are still able to stretch and to grow. Therefore, they are found in younger, still growing plant parts. The fibrous sclerenchym cells have a low tensibility as long as the cell walls are not yet lignified. Supporting tissues occur in different places depending on stress acting on different plant parts. The flexural rigidity of sprouts must be high so that the strengthening tissue must 


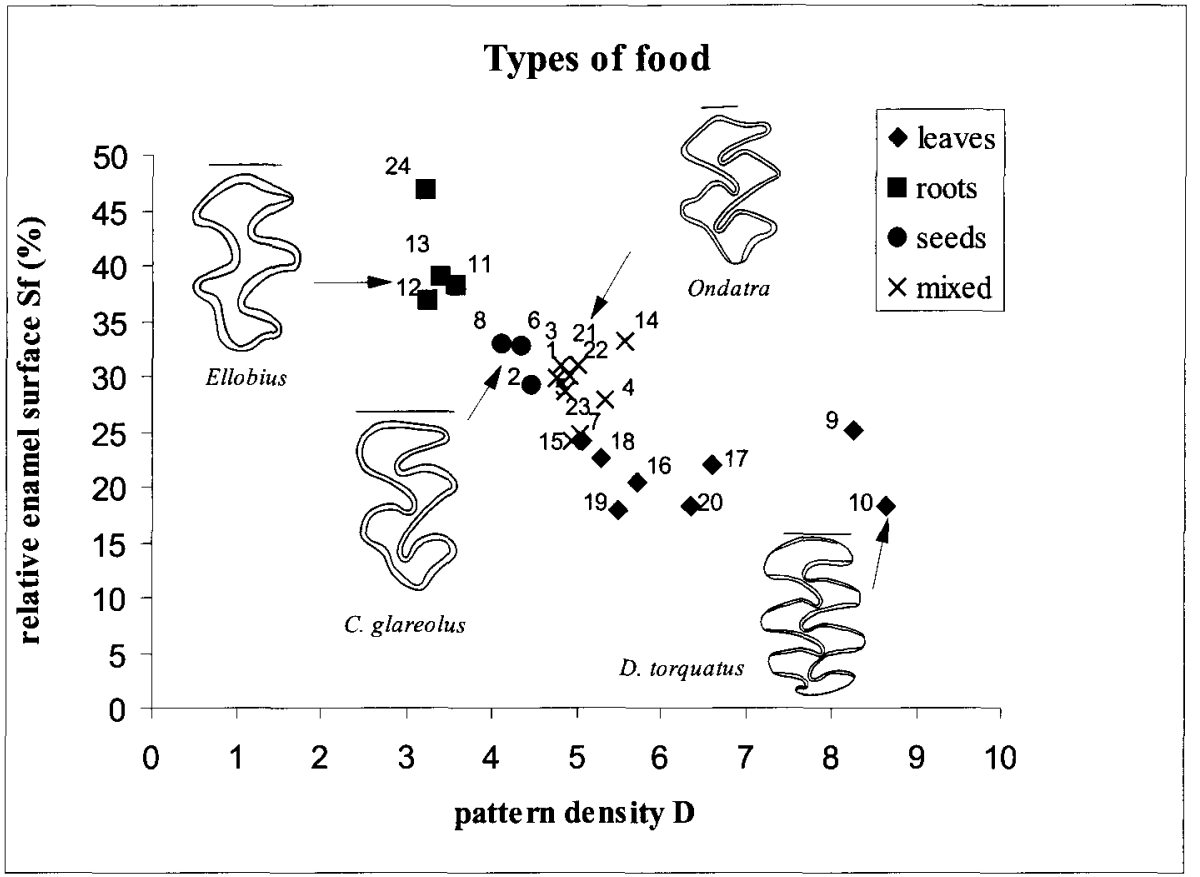

Text-fig. 9. Gradually changing dental patterns of upper $\mathrm{M}^{2}$ with regard to diet. (1) Alticola argentatus, (2) Alticola roylei montosa, (3) Alticola semicanus,(4) Arvicola sapidus, (5) Arvicola terrestris,(6) Clethrionomys glareolus, (7) Clethrionomys rufocanus, (8) Clethrionomys rutilus, (9) Dicrostonyx groenlandicus, (10) Dicrostonyx torquatus, (11) Ellobius fuscocapillus, (12) Ellobius nitedula angelus, (13) Ellobius talpinus, (14) Lagurus curtatus, (15) Lagurus lagurus, (16) Lemmus lemmus, (17) Microtus agrestis, (18) Microtus arvalis, (19) Microtus oeconomus, (20) Myopus schisticolor, (21) Ondatra zibethicus, (22) Pitymys lusitanicus, (23) Pitymys subterraneus, (24) Prometheomys schaposchnikovi

be peripheral. Tension is the main stress acting on roots, what means that the strengthening tissue must be central. Leaves should not rip off. Therefore the strengthening tissues are arranged parallel the long axis of the leaf and surround the vessels (NULTSCH, 1996). Leaves of grass are not lignified but very tensile because their strengthening tissues are distributed. This means, leaves are not as tough as roots, which latter are lignified (with the exception of delicate root hairs) and have a bundle of strengthening tissue. The envelopes of seeds consist of very lignified stone cells (text-fig. 10).

Hard parts can be destroyed by pressure applied by blunt surfaces. Thin and tensile materials can only be cut by sharp cutting edges. The development of effective cutting edges was necessary in order to reduce leaves and young sprouts of grass to small pieces.

Contaminations of sand or soil minerals increase the abrasion effect associated with a diet of roots so that adaptations were likewise necessary. Enamel thickness of root feeding species increases from $0.08-0.1 \mathrm{~mm}$ in the primitive species to $0.14 \mathrm{~mm}$ in Prometheomys (Koenigswald, 1980). A thick and blunt enamel band increases crack resistance. Therefore, the increased enamel thickness of root feeding species is a specialization of a diet with contaminations. Thus, in arvicolids there are specializations of a grass and moss diet on the one hand and a root diet on the other.

\section{Food specialization and direction of enamel edges}

Text-fig. 8 shows that the enamel bands of species, which do not or not frequently feed on grass, have two maxima in the directions of the enamel band. Contrary to that, enamel bands of grass and moss feeding species have only one preferred direction. This means the shape of the anticlines of grass and moss feeders, especially the genera Dicrostonyx, Lemmus, Myopus, is like a U. The limbs of the dentin triangles are nearly parallel (text-fig. 5, Dicrostonyx). In addition, the enamel bands are reduced at the vertexes. As a whole, parameter $G$ and the direction of enamel edges are more depended on the type of occlusal patterns than the specialization of a diet. In spite of its diet of grass the dental patterns of Clethrionomys rufocanus have the same dominating direction as the other species of this genus because its occlusal surface is derived from the same basic pattern type. For this reason, the variability of parameter $\mathrm{G}$ of the arvicolids is not high, but the G-values of grass and moss feeding species are somewhat higher than those of the other species (Tab. 2)

\section{Diet and systematics}

Text-fig. 9 shows that a strict specialization to a special diet influences the adaptations of dental patterns more than the membership to a particular genus. Thus, Clethrionomys rufocanus with nearly the same diet as Microtus in the parameters D and Sf is clearly different from the two other analysed species of the genus. The Sf-value of Pitymys subterraneus is also different from $P$. lusitanicus, which latter feeds more on roots. Relatively thick enamel bands of Lagurus curtatus point to a more root- and seeds-rich diet of $L$. lagurus. This shows that the relative enamel surface $\mathrm{Sf}$ is the best indicator for recognizing a specialization to a particular diet (SCHMIDT-KITTLER, 2001).

Changes in dental patterns are gradual, so that all transitions from mixed diet to a more exclusive grass-rich or rootrich diet exist.

\section{Comparison of upper- and lower cheek teeth}

In this study, mostly complete skulls of Recent species were analysed so that it was possible to consider teeth of upper and lower jaws of the same individuals.

Comparison of the parameters of molars of upper- and lower jaw shows that all Sf- and D-values of the lower jaw are 


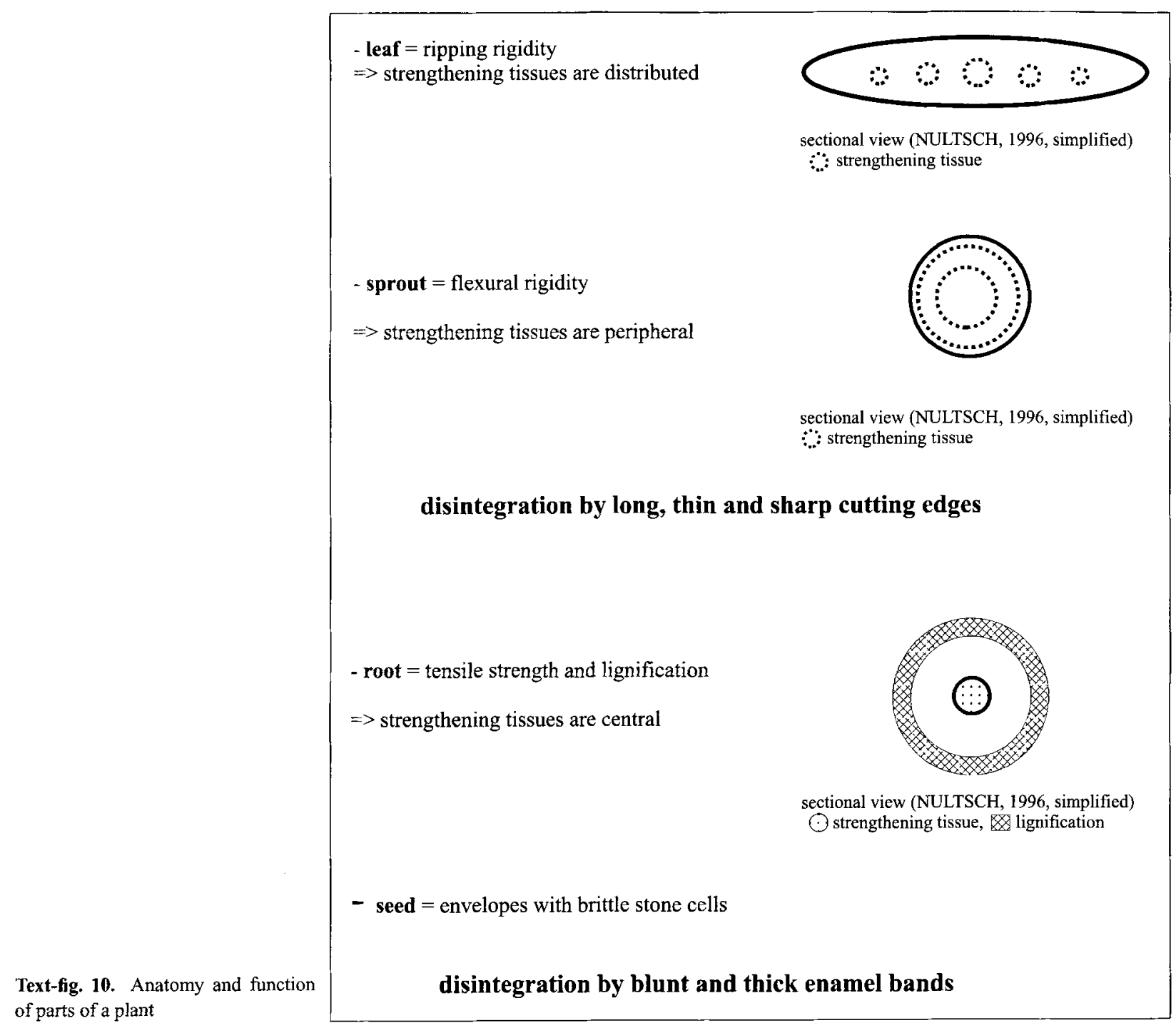

higher than those of the upper jaw (text-fig. 11). These differences are caused by an additional labial-anticline of the occlusal patterns of $\mathrm{M}_{2}$. Dicrostonyx groenlanicus, D. toquatus and Microtus agrestis are exceptions because their dental patterns deviate in the number of dentin triangles of the basic type (textfig. 12). The functional symmetry (KoENIGSWALD, 1994) of upper and lower M2 of these species is very high, because both M2 have the same number of dentin triangles and show similar D- and Sf-values. Only the G-values and the sizes of the occlusal surfaces are different. The particularities of Prometheomys are not discussed because there was only one individual of this species at hand. Sf-values of lower $\mathrm{M}_{2}$ of the voles and lemmings are in the average $7 \%$ higher than those of the upper $\mathrm{M}^{2}$. In the D-values the average difference is $6 \%$. No correlation in the occlusal surfaces of the molars $\left(F_{\text {ges }}\right)$ can be stated, because in the lower jaws they either possess higher or lower values than in the upper jaws (table 2 and table 3).

In spite of the common tendency toward functional symmetry (KOENIGSWALD, 1994), differences in patterns and sizes of occlusal surfaces of upper and lower jaws are necessary and can be explained functionally. If the patterns would be exactly the same all cutting edges operating at the same time and after that such a phase would be no cutwork would be done until the following edges contact. There would be phases with a big effort and rest-phases during the stroke. Energetically more efficient is a fairly constant effort. This can be achieved by simple pattern-displacements and is expressed in different values of parameters, or different sizes of the occlusal surfaces.

\section{Conclusions}

Differences in dental patterns of the Arvicolinae are correlated with different diet. The two different food-specializations to roots (low pattern density and relatively thick enamel bands) or to leaves of grasses (high pattern density and low relative enamel surface) could be characterized. Thin, sharp and uniformly orientated enamel edges are necessary to cut thin and tough leaf fibres. Hard seeds and roots with more or less contamination of soil need thick and blunt enamel bands in order 


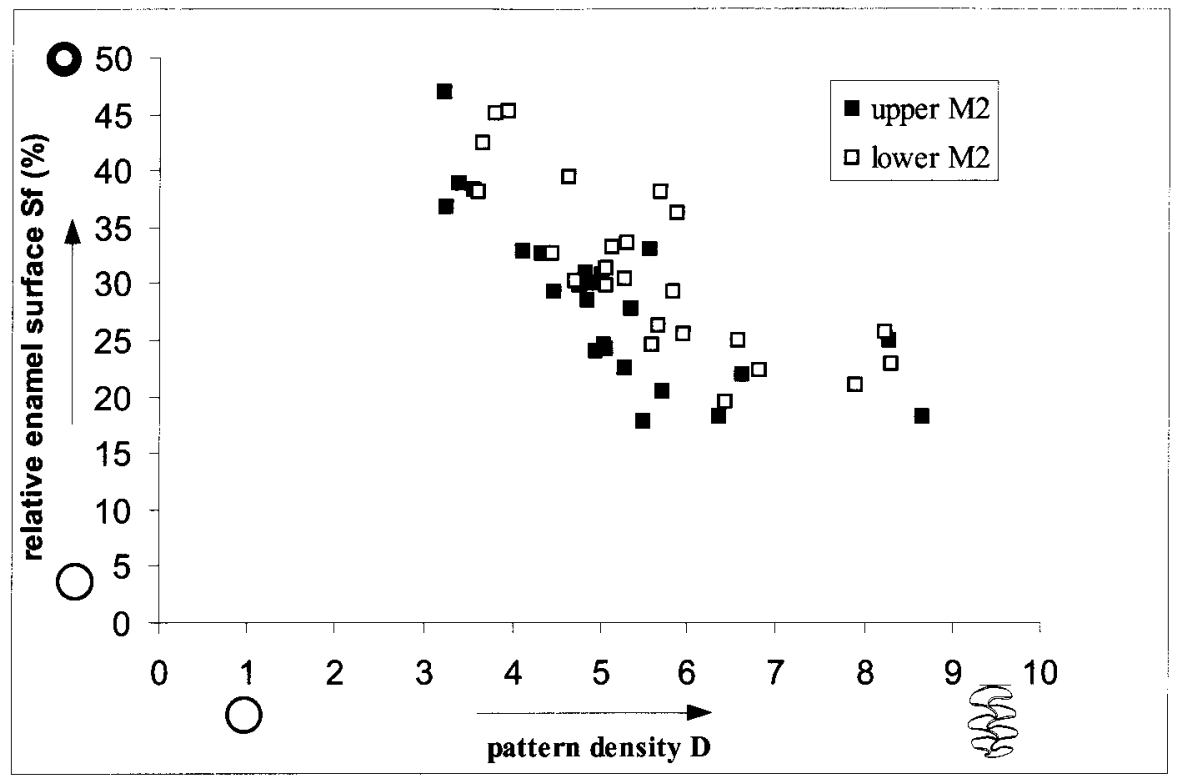

Text-fig. 11. Comparison of parameters $\mathrm{D}$ and $\mathrm{Sf}$ of upper and lower M2 of arvicolid species. to be reduced food to small pieces. The dental patterns analysed change gradually.

Using structural parameters makes it possible to recognize and to represent smallest modifications of occlusal patterns. Thanks the parameters D and Sf, it is recognizable that in spite of increasing pattern density the relative enamel surface decreases because the enamel edges become thinner and uneffective parts will be reduced. Reduction of thickness of the enamel bands decreases the surface of contacts between upper and lower molars. Due to that, the punctual pressure compo-
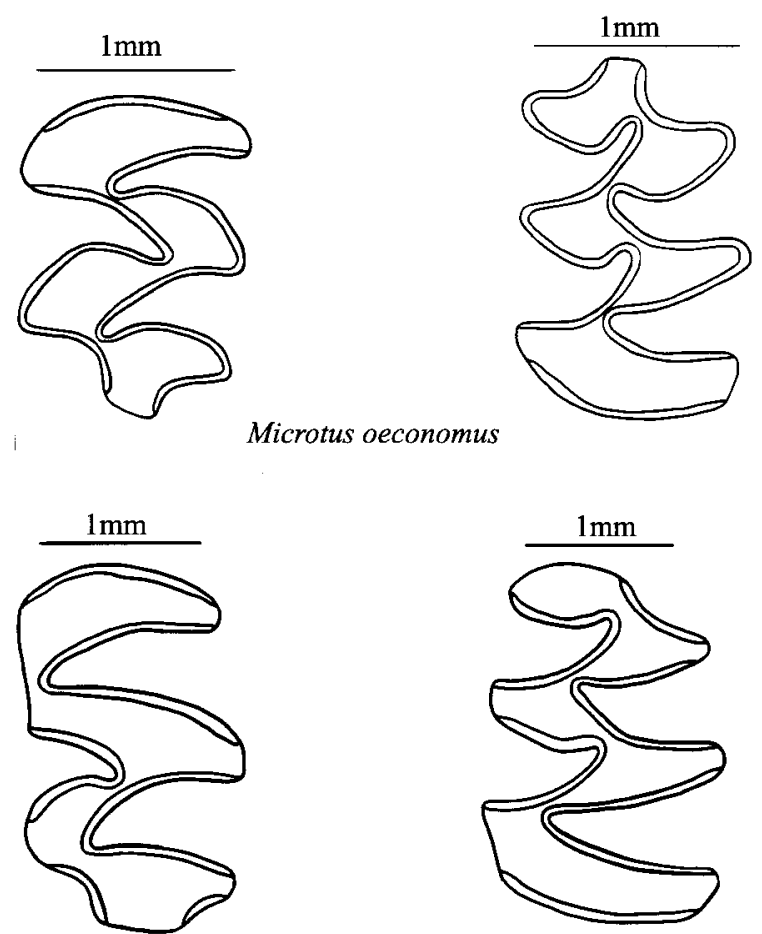

Lemmus lemmus nents derived from the jaw muscles become higher and improve the cutting separation. Parameters Sf and G showed that thinner and more uniformly orientated enamel edges increase the effectivity of cutting separation. Thanks to the measurements of angles of the enamel bands to the direction of chewing motion, it is recognizable that the horizontal pressure component increases with an angle not much deviated from $90^{\circ}$ and compression of food will be improved.

Dicrostonyx has the highest evolved cutting dentition of Arvicolinae.
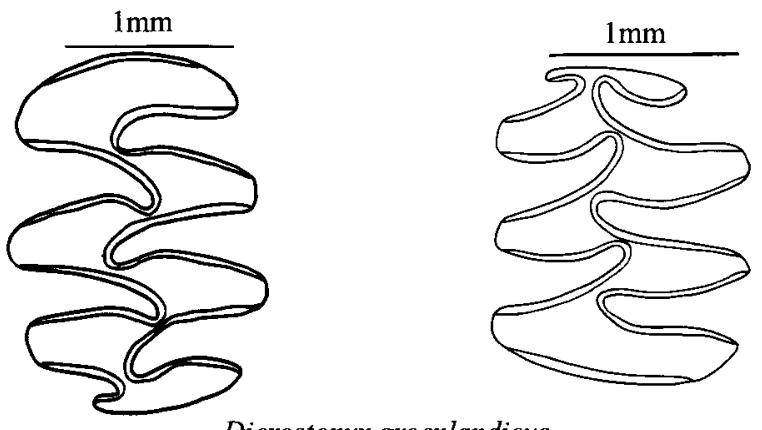

Dicrostonyx groenlandicus
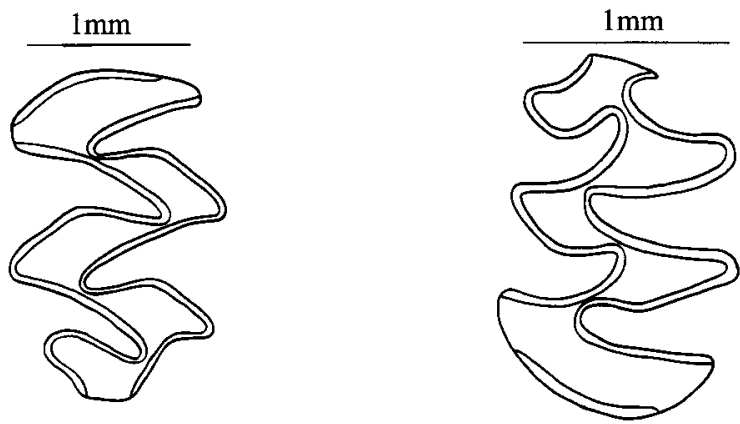

Microtus agrestis

Text-fig. 12. Differences of the occlusal patterns of left upper and lower M2. 
Functional symmetry of upper and lower M2 of the analysed species is high, especially in Dicrostonyx groenlanicus, D. toquatus and Microtus agrestis. However, small differences of dental patterns of M2 in both jaws are necessary because the slightly displaced enamel edges lead to a permanent cutwork and a constant pressure and effort during the mastication process.

Analysis of the fossil arvicolids should make it possible to ascertain the degree of specialization to grass diet through the change of structural parameters. This study is the second part of my dissertation.

\section{Acknowledgements}

I thank the reviewer Prof. Dr. W. V. Koenigswald for valuable comments and discussion. Dipl. Ing. Mirko Siebold, Fachhochschule für Geoinformatik Mainz, is thanked for developing a calculation program for parameter G. I am grateful to Dr. G. STORCH, Forschungsinstitut Senckenberg Frankfurt, and Dr. D. MöHRICKE, Museum für Naturkunde Stuttgart, for lending me a considerable amount of material. Thanks are due to Prof. Dr. W.D. HeInRICH, Universität Berlin, Prof. Dr. Frank, Universität Stuttgart, Prof. Dr. W. BÄUMLER, Universität München, Dr. C. MÖDDEN, Universität Mainz, and Prof. Dr. W. BÖHLER, Fachhochschule Mainz, for their help. The financial support given by the Deutsche Forschungsgemeinschaft is gratefully acknowledged.

\section{Tables}

Table 1: Material.

\begin{tabular}{|c|c|c|}
\hline species & number of $\mathrm{M} 2 ; \mathrm{M} 2$ & from \\
\hline (1) Alticola argentatus & $12 ; 11$ & Kirgisia, Berlin \\
\hline (2) Alticola roylei montosa & $2 ; 2$ & Afghanistan \\
\hline (3) Alticola semicanus & $4 ; 4$ & Berlin \\
\hline (4) Arvicola sapidus & $9 ; 9$ & Spain \\
\hline (5) Arvicola terrestris & $38 ; 36$ & Switzerland, Germany, Spain, Yugoslavia \\
\hline (6) Clethrionomys glareolus & $19 ; 17$ & Austria, Germany \\
\hline (7) Clethrionomys rufocanus & $18 ; 18$ & Norway, Sweden, Finland \\
\hline (8) Clethrionomys rutilus & $15 ; 15$ & Norway, Sweden, Finland \\
\hline (9) Dicrostonyx groenlandicus & $13 ; 19$ & Canada \\
\hline (10) Dicrostonyx torquatus & $8 ; 8$ & Sibiria \\
\hline (II) Ellobius fuscocapillus & $4 ; 4$ & U.S.S.R., Turkey \\
\hline (12) Ellobius nitedula angelus & $2 ; 2$ & Kirgisia \\
\hline (13) Ellobius talpinus & $6 ; 6$ & Russia, China \\
\hline (14) Lagurus curtatus & $4 ; 4$ & California \\
\hline (15) Lagurus lagurus & $11 ; 7$ & Russia \\
\hline (16) Lemmus lemmus & $17 ; 15$ & Norway, Sweden \\
\hline (17) Microtus agrestis & $20 ; 12$ & Austria, Germany \\
\hline (18) Microtus arvalis & $23 ; 16$ & Yugoslavia, Germany, Greece, Turkey \\
\hline (19) Microtus oeconomus & $23 ; 17$ & Austria, Norway, Sweden \\
\hline (20) Myopus schisticolor & $7 ; 6$ & Sweden, Finland \\
\hline (21) Ondatra zibethicus & $32 ; 29$ & Germany, Ohio \\
\hline (22) Pitymys lusitanicus & $19 ; 14$ & Portugal, Spain \\
\hline (23) Pitymys subterraneus & $23 ; 23$ & Slovakia, Germany, Hungary \\
\hline (24) Prometheomys schaposchnikovi & $2 ; 2$ & Caucasus \\
\hline
\end{tabular}


Table 2: General view of values of the parametres $D, S f$ and $G$ of upper $M_{2}$.

\begin{tabular}{|c|c|c|c|c|}
\hline species & $\mathrm{D}$ & $\mathrm{Sf}(\%)$ & $\mathrm{G}$ & Fges $\left(\mathrm{mm}^{2}\right)$ \\
\hline \hline (I) Alticola argentatus & 4,76 & 29,83 & 2,14 & 1,02 \\
\hline (2) Alticola roylei montosa & 4,46 & 29,29 & 2,23 & 1,04 \\
\hline (3) Alticola semicanus & 4,82 & 30,95 & 2,37 & 1,06 \\
\hline (4) Arvicola sapidus & 5,35 & 27,77 & 2,84 & 3,44 \\
\hline (5) Arvicola terrestris & 4,85 & 28,63 & 2,47 & 2,59 \\
\hline (6) Clethrionomys glareolus & 4,32 & 32,66 & 2,2 & 0,85 \\
\hline (7) Clethrionomys rufocanus & 5,06 & 24,18 & 2,49 & 1,12 \\
\hline (8) Clethrionomys rutilus & 4,11 & 32,93 & 2,41 & 0,8 \\
\hline (9) Dicrostonyx groenlandicus & 8,25 & 25,09 & 7,08 & 1,58 \\
\hline (10) Dicrostonyx torquatus & 8,63 & 18,16 & 8,83 & 1,63 \\
\hline (11) Ellobius fuscocapillus & 3,56 & 38,28 & 2,23 & 2,2 \\
\hline (12) Ellobius nitedula angelus & 3,25 & 36,86 & 2,16 & 1,98 \\
\hline (13) Ellobius talpinus & 3,39 & 38,93 & 1,89 & 1,89 \\
\hline (14) Lagurus curtatus & 5,57 & 33,1 & 2,44 & 1,34 \\
\hline (15) Lagurus lagurus & 4,93 & 24,04 & 2,72 & 1,01 \\
\hline (16) Lemmus lemmus & 5,71 & 20,49 & 5,71 & 1,8 \\
\hline (17) Microtus agrestis & 6,62 & 22 & 4,38 & 1,2 \\
\hline (18) Microtus arvalis & 5,28 & 22,64 & 3,14 & 1 \\
\hline (19) Microtus oeconomus & 5,49 & 17,9 & 3,3 & 1,23 \\
\hline (20) Myopus schisticolor & 6,35 & 18,14 & 6 & 1,37 \\
\hline (21) Ondatra zibethicus & 5 & 30,9 & 3,67 & 6,54 \\
\hline (22) Pitymys lusitanicus & 4,9 & 30,02 & 2,56 & 0,89 \\
\hline (23) Pitymys subterraneus & 5,03 & 24,67 & 2,69 & 0,98 \\
\hline (24) Prometheomys schaposchnikovi & 3,22 & 46,9 & 4,31 & 2,57 \\
\hline & & & & \\
\hline
\end{tabular}

Table 3: Values of $\mathrm{M}_{2}$.

\begin{tabular}{|c|c|c|c|c|}
\hline species & $\mathrm{D}$ & $\mathrm{Sf}(\%)$ & $\mathrm{G}$ & Fges $\left(\mathrm{mm}^{2}\right)$ \\
\hline \hline (I) Alticola argentatus & 5,07 & 31,43 & 3,08 & 0,91 \\
\hline (2) Alticola roylei montosa & 4,69 & 30,3 & 3,34 & 0,88 \\
\hline (3) Alticola semicanus & 5,29 & 33,66 & 3,31 & 1,03 \\
\hline (4) Arvicola sapidus & 5,82 & 29,4 & 3,21 & 3,2 \\
\hline (5) Arvicola terrestris & 5,28 & 30,44 & 3,11 & 2,43 \\
\hline (6) Clethrionomys glareolus & 4,44 & 32,7 & 3,21 & 0,84 \\
\hline (7) Clethrionomys rufocanus & 5,58 & 24,63 & 2,91 & 1,07 \\
\hline (8) Clethrionomys rutilus & 4,64 & 39,43 & 3,14 & 0,8 \\
\hline (9) Dicrostonyx groenlandicus & 8,2 & 25,73 & 6,25 & 1,31 \\
\hline (10) Dicrostonyx torquatus & 8,28 & 22,9 & 6,69 & 1,37 \\
\hline (11) Ellobius fuscocapillus & 3,66 & 42,39 & 2,68 & 2 \\
\hline (12) Ellobius nitedula angelus & 3,61 & 38,14 & 3,24 & 1,77 \\
\hline (13) Ellobius talpinus & 3,8 & 45,16 & 2,84 & 1,71 \\
\hline (14) Lagurus curtatus & 5,69 & 38,14 & 2,96 & 1,12 \\
\hline (15) Lagurus lagurus & 5,66 & 26,34 & 3,89 & 0,74 \\
\hline (16) Lemmus lemmus & 6,79 & 22,3 & 5,83 & 1,8 \\
\hline (I7) Microtus agrestis & 6,57 & 24,95 & 3,65 & 1,08 \\
\hline (18) Microtus arvalis & 5,94 & 25,56 & 3,37 & 0,94 \\
\hline (19) Microtus oeconomus & 6,42 & 19,64 & 3,62 & 1,17 \\
\hline
\end{tabular}


Table 3: Values of $\mathrm{M}_{2}$.

\begin{tabular}{|c|c|c|c|c|}
\hline species & $\mathrm{D}$ & $\mathrm{Sf}(\%)$ & $\mathrm{G}$ & Fges $\left(\mathrm{mm}^{2}\right)$ \\
\hline \hline (20) Myopus schisticolor & 7,87 & 20,99 & 5,67 & 1,36 \\
\hline (21) Ondatra zibethicus & 5,86 & 36,19 & 5,25 & 5,57 \\
\hline (22) Pitymys lusitanicus & 5,13 & 33,19 & 3,03 & 0,72 \\
\hline (23) Pitymys subterraneus & 5,06 & 29,93 & 3,03 & 0,83 \\
\hline (24) Prometheomys schaposchnikovi & 3,93 & 45,38 & 3,74 & 3,02 \\
\hline
\end{tabular}

\section{References}

Agadjanian, A.K. (1983): eine altertümliche Arvicola (Rodentia, Mammalia) aus dem Mittelpleistozän der Russischen Ebene. - In: HEINRICH, W.-D. [ed], Wirbeltier-Evolution und Faunenwandel im Känozoikum: 9-29, 7 Abb., 5 Tab.; Schriftenr. Geol. Wiss. Berlin 19/20; Berlin (Akademie-Verlag)

BALMELLl, L., NENTWIG, W., AIROLDI, J.-P. (1999): Nahrungspräferenzen der Feldmaus Microtus arvalis in der Agrarlandschaft unter Berücksichtigung der Pflanzeninhaltsstoffe. - Z. Säugetierkunde, 64: 154-168.

BÄUMLER, W. (1992): Köderscheu bei Wühlmäusen (Microtinae). Anzeiger für Schädlingskunde, Pflanzenschutz, Umweltschutz, 65 65-67.

Chaline, J., Brunet-lecomte, P., Brochet, G., Martin, F. (1989) Les lemmings fossiles du genre Lemmus (Arvicolidae, Rodentia) dans le Pleistocene de France.-Geobios, 22: 613-623

FEJFAR, O., HEINRICH, W.-D. (1983): Arvicoliden-Sukzession und Biostratigraphie des Oberpliozäns und Quartärs in Europa. - In: HEINRICH, W.-D. [ed], Wirbeltier-Evolution und Faunenwandel im Känozoikum: 61-109, 2 Abb., 1 Tab.; Schriftenr. Geol. Wiss. Berlin 19/20; Berlin (Akademie-Verlag).

FRANK, F. (1954): Beiträge zur Biologie der Feldmaus, Microtus arvalis (Pallas),-Zool. Jahrbücher, 82 (3/4): 355-404.

JANIS, C.M., FoRTELIUS, M. (1988): On the means whereby mammals achieve increased functional durability of their dentitions, with special reference to limiting factors. - Biological Reviews, 63: 197 230

KOENIGSWALD, W. vON (1980): Schmelzstruktur und Morphologie in den Molaren der Arvicolidae (Rodentia). - Abh. Senckenb. Naturforsch. Ges, 539: 1-129, 136 Abb.; Frankfurt/M (Waldemar Kramer)

Koenigswald, W. von, SAnder, P.M., LetTe, M.B., Mörs, T., SANTEL, W. (1994): Functional symmetries in the schmelzmuster and morphology of rootless rodent molars. - Zoological Journal of Linnean Society, 110: 141-179.

MAGLIO, V.J. (1972): Evolution of mastication in the Elephantidae. Evolution, 26: 638-658.

MosBRUGGER, V. (1990): The tree habit in land plants: a functional

comparison of trunk constructions with a brief introduction into biomechanics of trees. - Berlin (Springer).

MÖDDEN, C. (1993): Revision der Archaeomyini Schlosser (Rodentia,

Mammalia) des europäischen Oberoligozäns. - Schweizerische Paläontologische Abhandlungen, 115: 1-83. Basel (Birkhäuser).

NieTHAMMER, J., KRAPP, F. (1988): Familie Arvicolidae Gray, 1821 Wühlmäuse. - In: Handbuch der Säugetiere Europas, Bd. 2/I Nagetiere II: 51 -496; Wiesbaden (Akademische Verlagsgesellschaft).
NulTSCH, W. (1996): Allgemeine Botanik.-Stuttgart, New York (Georg Thieme).

RENSBERGER, J.M. (1995): Determination of stresses in mammalian dental enamel and their relevance to the interpretation of feeding behaviors in extinct taxa. - In: THOMASON, J.J. [ed], Functional morphology in vertebrate paleontology; Australia (Cambridge University press).

RENSBERGER, J.M. (1973): An occlusion model for mastication and dental wear in herbivorous mammals. - J.Paleont., 47: 515-528

RENSBERGER, J.M., FORSTEN, A., FORTElius, M. (1984): Functional evolution of cheek teeth pattern and chewing direction in Tertiary horses. - Paleobiology, 10 (4): 439-452.

SCHMIDT-KITTLER, N. (this volume): Feeding specializations in Rodents- a case study of structural and gradual evolution. Senckenbergiana lethaea 82 (1): 141-152.

SCHMIDT-KITTLER, N. (1984): Pattern analysis of occlusal surfaces in hypsodont herbivores and ist bearing on morpho-functional studies.Proceedings, B87 (4): 453-480.

SCHMIDT-KITTLER, N. (1986): Evaluation of occlusal patterns of hypsodont rodent dentitions by shape parameters. - N. Jb. Geol. Paläont. Abh., 173: 75-98

Siegel-CAUSEY, D., HofFMANN, R.S. (1992): Voles (Microtinae). - In: Gromov, I.M., POLYAKOV, I.YA. [eds], Fauna of the USSR-Mammals. - Vol.III, No.8; Washington (Smithonian Institution Libraries and National Science Found.).

SPITZEnberger, F., STEINER, H.M. (1965): Prometheomys schaposchnikovi Satunin, 1901, in Nordost-Kleinasien. - Z. Säugetierkunde, 29: 116-124

Ventura, J., GOSALBEZ, J., LoPEZ-Fuster, M.J. (1989): Trophic ecology of Arvicola sapidus MILLER, 1908 (Rodentia, Arvicolidae) in the Ebro Delta (Spain). - Zool. Anz., 223 (5/6): 283-290; Jena (VEB Gustav Fischer).

FoITH, J.H. (1984): Die Schermaus (Arvicola terrestris L.) und ihre Bekämpfung mit Fallen und Difenacoum in einem Forstpflanzgarten. - Diplomarbeit der Forstwissenschaftlichen Fakultät der Ludwig-Maximilians-Universität München (Betreuer Prof. Dr. W. Bäumler).

SEIFERT, T. (1997): Untersuchungen über einige morpho-physiologische Parameter und über die Fangbarkeit der Schermaus (Arvicola terrestris) mit arteigenen Duftstoffen. - Diplomarbeit der Forstwissenschaftlichen Fakultät der Ludwig-Maximilians-Universität München (Betreuer Prof. Dr. W. BÄUMLER). 